\title{
Extreme-Value Characteristics in Daily Time Series of Swedish Stock Returns*
}

\author{
Kurt Brännäs, Shahiduzzaman Quoreshi and Ola Simonsen \\ Department of Economics \& USBE, Umeå University \\ SE-901 87 Umeå, Sweden
}

\begin{abstract}
The paper studies Swedish stock series using extreme-value theoretical approaches. In a univariate setting support is found for the Fréchet family of distributions for minima and maxima. Pairs of return series are found to be asymptotically independent throughout. The results render support for joint modelling based on flexible moment specifications or, e.g., copulas.
\end{abstract}

Key Words: Value-at-Risk, minimum/maximum return, crossing.

JEL Classification: C14, C22, C32, G11, G12.

Umeå Economic Studies 597, 2002

\section{INTRODUCTION}

This paper studies empirically the extreme-value behavior of Swedish stock returns. One intention is to characterize the type of limiting extreme-value distribution for minima and maxima of the series. A second objective is to study the dependence between extreme returns of different stocks. Both objectives have clear ties to value-at-risk and to protecting a portfolio against extreme risk.

Methodologywise we employ standard tools for the univariate analysis of individual return series (e.g., Longin, 2000, Tsay, 2002, ch. 7). We give an account of the framework in Section 2. Also in Section 2, we focus on bivariate returns and give a brief account of the recently proposed approach of Poon, Rockinger and Tawn (2002). Both the univariate and bivariate approaches are essentially based on sequences of independent and identically distributed random variables. In the univariate setting a weak dependence in the return series still yields consistent estimation. For the bivariate case, e.g., Poon et al. (2002) employ corrections for conditional heteroskedasticity.

\footnotetext{
* The partial financial support from the Wallander-Hedelius Foundation and Umeå School of Business
} and Economics (USBE) is gratefully acknowledged. 
The included time series are defined and described in Section 3. The stocks used for the study are those that underlied standardized stock options at the Stockholm stock exchange (Stockholmsbörsen) in the spring of 2002. Byström (2001) appears to be the only study to use extreme-value theoretical approaches to study aspects of the Swedish stock market, in his case an index. In Section 4 we report the empirical results. Some concluding comments are given in the final section.

\section{The Extreme-Value Approach}

In this section we start by giving some of the essential steps in an extreme-value approach to the value at risk, VaR, in a univariate context. Full length accounts of this research area can be found in, e.g., Longin (2000) or in Tsay (2002, ch. 7), who builds on Longin. Later, we discuss the bivariate case which enables us to consider associations between extremes. The adopted approach builds on Poon et al. (2002).

\subsection{Single Series}

There is a time series of daily returns $r_{t}$ of length $T$. Returns are here and in the sequel defined to be percent day-to-day changes in stock prices. To estimate unknown parameters and probabilities we consider sub-periods of length $n$ of the return series. Assuming independence between returns and a common distribution $F$, the distribution for the smallest value $r_{1}$ among $n$ returns has the distribution function

$$
F_{r_{1}}(x)=1-[1-F(x)]^{n} .
$$

This holds since if $r_{1}>x$ then all $r_{i}>x$ and the probability for this event is $1-F_{r_{1}}(x)=$ $[1-F(x)]^{n}$.

In each such sub-period of length $n$ there is a minimum value that we now denote $r_{n i}$ with $i$ indicating the sub-period. There is $g$ such sub-periods and minimum values in the series, so that the total time series length is $T \geq n g$. In case $n g<T$ we drop the first few observations of the first sub-period so that all sub-periods are of equal length $n$.

Assume that $r_{n i}$ follows a limiting generalized extreme-value distribution for minimum values. The density has the form (for $k$ different from zero)

$$
f\left(r_{n i}\right)=\frac{1}{\alpha}\left[1+\frac{k\left(r_{n i}-\beta\right)}{\alpha}\right]^{1 / k-1} \exp \left\{-\left[1+\frac{k\left(r_{n i}-\beta\right)}{\alpha}\right]\right\}
$$

where $1+k\left(r_{n i}-\beta\right) / \alpha>0$ and $\alpha, \beta$ and $k$ are unknown parameters. The $k$ is a shape parameter that mirrors the tail behavior of the distribution. In financial time series there appears to be some support for $k<0$, in which case the distribution is in the Fréchet family and has negative skewness. The $\beta$ is a location and $\alpha$ is a scale parameter.

The corresponding density for maximum values is of a related type:

$$
f\left(r_{n i}\right)=\frac{1}{\alpha}\left[1-\frac{k\left(r_{n i}-\beta\right)}{\alpha}\right]^{1 / k-1} \exp \left\{-\left[1-\frac{k\left(r_{n i}-\beta\right)}{\alpha}\right]\right\} .
$$


For maximum values we expect positive skewness.

The maximum likelihood estimator maximizes the log-likelihood function

$$
\ln L(\alpha, \beta, k)=\sum_{i=1}^{g} \ln f\left(r_{n i}\right)
$$

with respect to the unknown parameters $(k, \beta, \alpha)$. If we estimate the parameters of the minimum density that density is used, while for maximum values the maximum density is used. Using simple numerical techniques it is found in practise that estimation is both very fast and numerically stable.

For the case of minimum values we can obtain a quantile $r^{*}$ corresponding to a small probability $p^{*}$ from the minimum distribution corresponding to the generalized extremevalue density, above, on the form

$$
r_{\text {min }}^{*}=\beta-\frac{\alpha}{k}\left\{1-\left[1-\ln \left(1-p^{*}\right)\right]^{k}\right\} .
$$

For the maximum distribution we have

$$
r_{\max }^{*}=\beta+\frac{\alpha}{k}\left\{1-\left[1-\ln \left(1-p^{*}\right)\right]^{k}\right\} .
$$

We may then use

$$
p^{*}=\operatorname{Pr}\left(r_{n i} \leq r^{*}\right)=1-\left[1-\operatorname{Pr}\left(r_{t} \leq r^{*}\right)\right]^{n}=1-(1-p)^{n}
$$

to relate the probability $p$ of the return series to the one for minima and sub-periods, i.e. $p^{*}$. Using this relationship, for a given small probability $p$, the value-at-risk, VaR, of holding a long position in the asset underlying the return $r_{t}$ is

$$
\mathrm{VaR}^{-}=\beta-\frac{\alpha}{k}\left\{1-[1-n \ln (1-p)]^{k}\right\}
$$

for $k$ different from zero. The VaR of holding a short position is of related form. The $(1-p)$ th quantile of the return is

$$
\mathrm{VaR}^{+}=\beta+\frac{\alpha}{k}\left\{1-[1-n \ln (1-p)]^{k}\right\} .
$$

In this case $p$ is a small probability that corresponds to the risk of holding a short position.

For multi-period VaR, Tsay $\left(2002\right.$, ch. 7) gives $\operatorname{Var}(h)=h^{-k} \operatorname{VaR}$, where $h$ is the time distance and $k$ is the shape parameter of the extreme-value distribution. Obviously, there are also other approaches to obtaining VaR measures (e.g., Gourieroux and Jasiak, 2002).

One very useful aspect in the robustness sense of the extreme-value approach is that no marginal distribution needs to be specified for the $\left\{r_{t}\right\}$ sequence. A second benefit is that the approach remains valid even when there is weak dependence in the $\left\{r_{t}\right\}$ sequence.

\subsection{Bivariate Series}

We first briefly consider the multivariate distribution of extreme returns. The account builds on Longin (2000) and takes multivariate minimal return to be a vector of univariate minimal 
returns over some time period. The $F$ is a $q$-dimensional limiting extreme-value distribution, if and only if (i) the univariate marginal distributions $F^{1}, F^{2}, \ldots, F^{q}$ are extreme-value distributions, and (ii) there is a dependence function $d$, which satisfies the condition

$$
F\left(r^{1}, \ldots, r^{q}\right)=1-\left[F^{1}\left(r^{1}\right) \cdots F^{q}\left(r^{q}\right)\right]^{d\left(r^{q}-r^{1}, \ldots, r^{q}-r^{q-1}\right)} .
$$

The dependence function has to be specified. For two extremes $r^{i}$ and $r^{j}$, Longin suggests the use of a measure due to Tiago de Oliviera (1973)

$$
d\left(r^{i}-r^{j}\right)=\rho_{i j} \frac{\max \left(1, \exp \left(r^{i}-r^{j}\right)\right)}{1+\exp \left(r^{j}-r^{i}\right)}+\left(1-\rho_{i j}\right) .
$$

The $\rho$ measure can be obtained for minimum and maximum values and compared to direct correlations between returns. In the bivariate and multivariate cases it appears that estimation will be more complicated.

Next, we consider the steps of the bivariate methodology of Poon et al. (2002). In this, the entire time series is utilized and rather than using sub-period maxima/minima we now consider up- and down-crossing of threshold levels.

First, we standardize the bivariate returns $r_{1 t}$ and $r_{2 t}$ to unit Fréchet marginals $s_{1 t}$ and $s_{2 t}$ by the transformations

$$
s_{1 t}=-1 / \ln F_{1}\left(r_{1 t}\right) \quad \text { and } \quad s_{2 t}=-1 / \ln F_{2}\left(r_{2 t}\right),
$$

where $F_{1}$ and $F_{2}$ are estimated as empirical distribution functions. The dependence structure between the upper tails of $s_{1}$ and $s_{2}$ is the same as for $r_{1}$ and $r_{2}$.

The standardized variables are on a common scale and extreme events of the form $s_{1}>c$ and $s_{2}>c$ are equally likely. The $c$ is a threshold for up-crossings. We say that $s_{1}$ and $s_{2}$ are perfectly dependent if $\operatorname{Pr}\left(s_{1}>c \mid s_{2}>c\right)=1$, they are exactly independent when $\operatorname{Pr}\left(s_{1}>c \mid s_{2}>c\right)=\operatorname{Pr}\left(s_{1}>c\right)$, which tends to zero as $c \rightarrow \infty$.

Define

$$
\chi=\lim _{c \rightarrow \infty} \operatorname{Pr}\left(s_{1}>c \mid s_{2}>c\right), \quad \chi \in[0,1] .
$$

We have asymptotic independence if $\chi=0$ and asymptotic dependence for $\chi>0$. A related measure is due to Coles, Heffernan and Tawn (1999):

$$
\bar{\chi}=\lim _{c \rightarrow \infty} \frac{2 \ln \operatorname{Pr}\left(s_{1}>c\right)}{\ln \operatorname{Pr}\left(s_{1}>c, s_{2}>c\right)}-1, \quad \bar{\chi} \in(-1,1] .
$$

For the bivariate normal case $\bar{\chi}$ equals the correlation coefficient. Otherwise, the sign of $\bar{\chi}$ corresponds to the type of association in the extremes.

To estimate $\bar{\chi}$, univariate extreme-value techniques are used. Let $z=\min \left(s_{1}, s_{2}\right)$ and sort to get $z_{(1)}<\ldots<z_{(T)}$. The estimator and its variance estimator are

$$
\begin{aligned}
\bar{\chi}^{*} & =\frac{2}{n_{c}}\left[\sum_{j=1}^{n_{c}} \ln \left(\frac{\bar{z}_{(j)}}{c}\right)\right]-1 \\
\operatorname{Var}\left(\bar{\chi}^{*}\right) & =\left(\bar{\chi}^{*}+1\right)^{2} / n_{c},
\end{aligned}
$$


where $n_{c}$ is the number of $z$-values exceeding $c$ and these $z$-values are labeled $\bar{z}$. If $\bar{\chi}^{*}$ is significantly smaller than one, we conclude that the variables are asymptotically independent and take $\chi=0$. If we cannot reject $\bar{\chi}=1$ then we estimate $\chi$. The estimator and its variance estimator are

$$
\begin{aligned}
\hat{\chi} & =c n_{c} / T \\
\operatorname{Var}(\hat{\chi}) & =c^{2} n_{c}\left(T-n_{c}\right) / T^{3} .
\end{aligned}
$$

A difficulty that appears to have no very satisfactory solution yet is the determination of the threshold level $c$. With the relatively large number of series to be analyzed in this paper we adopt a simple solution of setting $c$ equal to the 95 percent order statistic in the $\left\{z_{(i)}\right\}$ sequence. Poon et al. (2002) found an estimate of 2 percent, which gives a smaller $n_{c}$. Longin and Solnik (2002) used a range of $c$ between 0 to 10 percentage points away from the sample mean. By a Monte Carlo based approach they find that on average the threshold should be placed such that 4-6 percent of the observations fall above (or below for minima) the threshold.

Another recent approach to non-constant correlation in a parametric setting is to use copulas. ${ }^{1}$ The copula connection to bivariate extremes is discussed by Coles et al. (1999).

For bivariate and multivariate cases the VaR is to be determined using

$$
p=\operatorname{Pr}\left(\mathbf{a}^{\prime} \mathbf{r}_{t} \leq v\right)=\operatorname{Pr}\left(\frac{\mathbf{a}^{\prime} \mathbf{r}_{t}-e}{s} \leq \frac{v-e}{s}\right)=F\left(\frac{v-e}{s}\right),
$$

where $\mathbf{a}$ is the allocation vector across the $m$ returns in the vector $\mathbf{r}$. Then $v=e+s F^{-1}(p)$, where $e=\mathbf{a}^{\prime} \mathrm{E}\left(\mathbf{r}_{t}\right)$ and $s=\mathbf{a}^{\prime} \operatorname{Var}\left(\mathbf{r}_{t}\right) \mathbf{a}$. For, e.g., the normal distribution case this has a well-known solution (e.g., Gourieroux and Jasiak, 2001, ch. 16). In the extreme-value context, Longin (2000) gives an ad hoc solution and Poon et al. (2002) give bounds for the $p$ probability. Using these bounds Poon et al. (2002) found that portfolio risk may be overestimated if asymptotic independence is not accounted for. For bivariate and multivariate extreme-value situations the evaluation currently requires parametric specification. We abstain from doing such assumptions and then give no full VaR results. Approximate and partial VaR measures can be obtained when we empirically find that asymptotic independence prevails. Then $\operatorname{Pr}\left(a r_{1}+(1-a) r_{2} \leq v \mid r_{1}>c, r_{2}>c\right)$ can be numerically evaluated using tail approximations.

\section{The Stock Series}

All stock series for which standardized derivatives exist at the Stockholmsbörsen stock exchange in Stockholm are studied. Return is defined as the one-day relative change (in percent) in the price. The time series are given in Table 1 with average returns and standard deviations over the full time series length. We note that the mean returns are positive and significantly different from zero in most cases. Note also that there is considerable variation in time series lengths.

\footnotetext{
${ }^{1}$ A copula is a function $C$ such that for known marginal distributions $F(x)$ and $G(y)$, the bivariate distribution function $H(x, y)=C[F(x), G(y)]$ is well defined. This too is emerging as a practical tool. Note, however, that it apparently requires a much more tightly specified model setup.
} 
Table 1: Stock series with descriptive statistics for daily returns in percent, period start (year, month, day all series end at 020307) and time series length, source: Stockholmsbörsen $\mathrm{AB})$.

\begin{tabular}{|c|c|c|c|c|}
\hline \multirow[b]{2}{*}{ Stock series } & \multirow{2}{*}{$\begin{array}{r}\text { Period } \\
\text { Start }\end{array}$} & \multicolumn{2}{|c|}{ Descriptives } & \multirow[b]{2}{*}{$T$} \\
\hline & & Mean & $\overline{d d e v}$ & \\
\hline ABB Ltd & 990622 & -0.07 & 2.83 & 683 \\
\hline Allgon & 880527 & 0.17 & 3.92 & 3454 \\
\hline Assa Abloy & 941108 & 0.20 & 2.64 & 1838 \\
\hline Astra Zeneca & 990406 & 0.06 & 1.89 & 736 \\
\hline Atlas Copco A & 870102 & 0.08 & 2.07 & 3810 \\
\hline Autoliv SDB & 970502 & 0.02 & 2.14 & 1216 \\
\hline Avesta Polarit & 010130 & 0.22 & 2.26 & 276 \\
\hline Boss Media & 990624 & 0.21 & 5.70 & 681 \\
\hline Electrolux B & 870102 & 0.05 & 2.09 & 3810 \\
\hline Eniro & 001010 & 0.05 & 2.87 & 353 \\
\hline Ericsson B & 870102 & 0.13 & 2.72 & 3810 \\
\hline Europolitan & 940527 & 0.15 & 3.02 & 1954 \\
\hline Föreningssparbanken & 950601 & 0.09 & 2.14 & 1692 \\
\hline Gambro B & 910718 & 0.04 & 2.05 & 2671 \\
\hline H\&M B & 870325 & 0.13 & 2.30 & 3751 \\
\hline Holmen B & 870325 & 0.07 & 2.65 & 3751 \\
\hline Investor B & 880418 & 0.07 & 2.19 & 3488 \\
\hline Kinnevik B & 921112 & 0.08 & 2.53 & 2338 \\
\hline MTG B & 990503 & 0.13 & 3.66 & 717 \\
\hline Nokia & 870320 & 0.17 & 3.22 & 3754 \\
\hline Nordea & 971208 & 0.07 & 2.48 & 1063 \\
\hline Pharmacia C & 000403 & 0.01 & 2.23 & 483 \\
\hline Sandvik AB & 870902 & 0.07 & 1.96 & 3643 \\
\hline SCA B & 870102 & 0.05 & 1.96 & 3809 \\
\hline Scania B & 960401 & 0.03 & 1.95 & 1485 \\
\hline SEB A & 870102 & 0.07 & 3.24 & 3810 \\
\hline Securitas & 920213 & 0.14 & 2.25 & 2527 \\
\hline SHB A & 870323 & 0.08 & 2.33 & 3755 \\
\hline Skandia & 870102 & 0.08 & 2.72 & 3810 \\
\hline Skanska & 870318 & 0.05 & 2.01 & 3756 \\
\hline SKF B & 870102 & 0.05 & 2.18 & 3810 \\
\hline Song Networks & 000316 & -0.48 & 8.68 & 495 \\
\hline SSAB A & 890703 & 0.06 & 2.34 & 3184 \\
\hline Stora Enso Ser R & 981229 & 0.11 & 2.67 & 801 \\
\hline Tele2 B & 960514 & 0.13 & 2.85 & 1457 \\
\hline Telia & 000613 & -0.13 & 3.11 & 437 \\
\hline Tieto Enator & 990709 & 0.04 & 3.78 & 671 \\
\hline Trelleborg B & 870324 & 0.06 & 2.42 & 3752 \\
\hline Volvo B & 870102 & 0.05 & 1.98 & 3810 \\
\hline WM-data & 870401 & 0.12 & 2.67 & 3746 \\
\hline
\end{tabular}




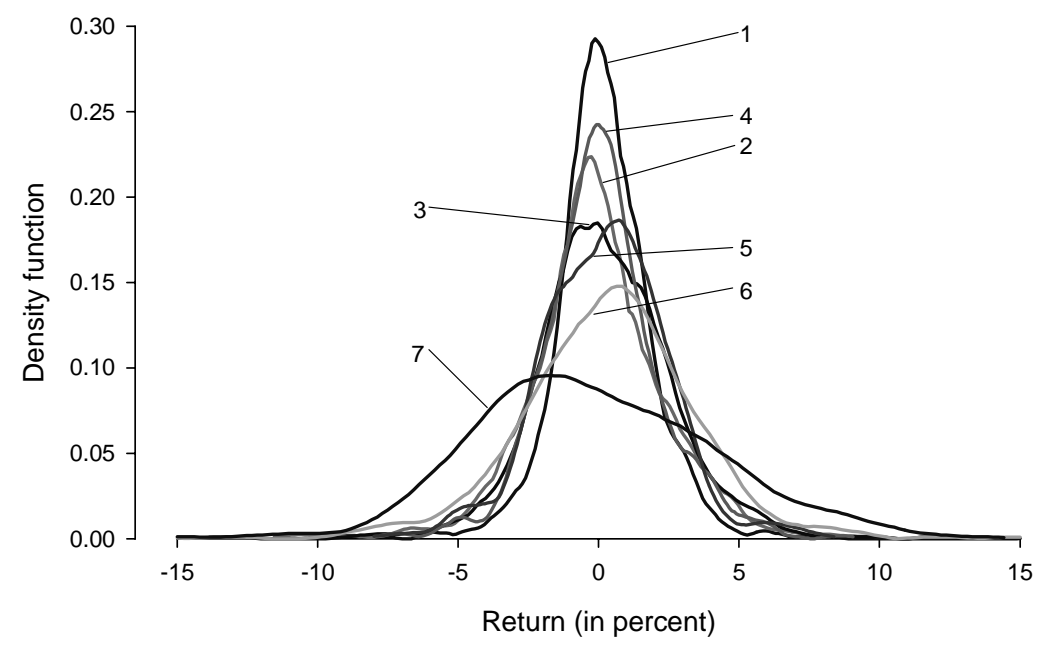

Figure 1: Estimated densities for two-year periods of Ericsson B 1987-01-01 - 2002-03-07 (kernel estimation, first sub-period is indicated by 1 and contains 810 observations, the later ones (indicated 2 to 7) 500 observations each).

We have employed the following pre-handling of the stock series: (i) splits and emissions are fully accounted for and (ii) a few missing observations in the price series are replaced by interpolated values.

\section{Empirical Results}

\subsection{Single Series}

The empirical results are based on sub-period lengths of $n=21$ days, i.e. corresponding to one month of trading. As there is some variation in time series lengths $T$, the number of sub-periods $g$ varies from series to series. Note also that all sub-periods are of equal length implying shorter total series lengths. We start by giving some rather detailed results for Ericsson B, before giving results for all other series in a more compact manner.

Figure 1 exhibits nonparametrically estimated density functions for Ericsson B in subperiods. It appears that there is substantial variation in the shapes of the densities. First, the densities vary between positive and negative skewness. Second, the variation (spread) varies substantially. Third, the mean return fluctuates around zero. Finally, it appears that there is a temporal pattern with more negative skewness and larger spreads in later periods.

Figure 2 shows graphically the main ingredients of the extreme value approach for the Ericsson B series. Roughly, the minimum density appears to be a reflection of the maximum density. The parameter estimates are given in Table 2 . The minimum density has $\hat{k}=-0.30$ and the maximum density $\hat{k}=-0.24$. Both are significantly different from zero, so that the Fréchet distribution cannot be rejected. 


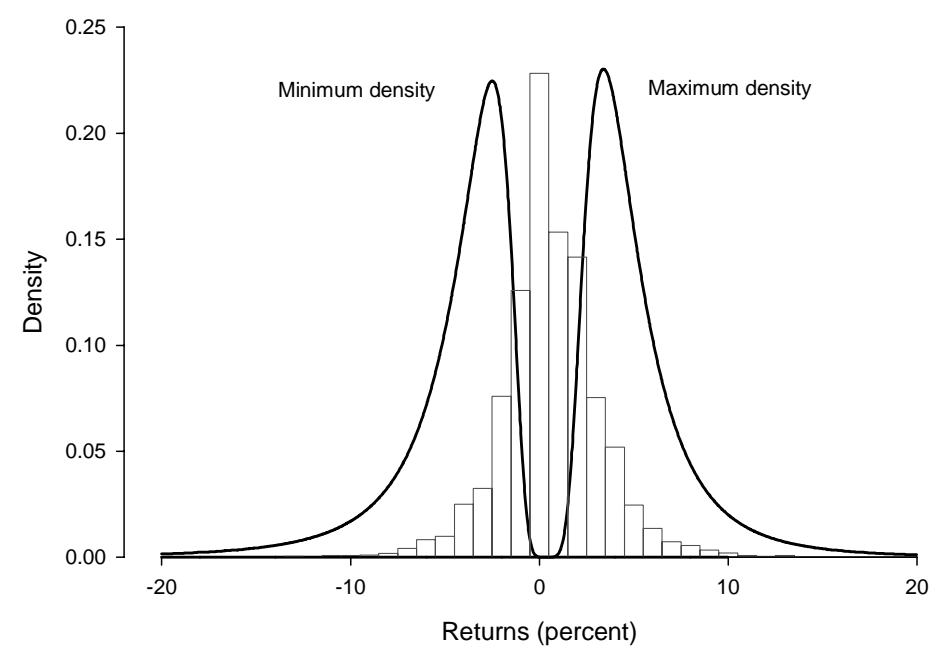

Figure 2: Histogram of full Ericsson B series, 1987-01-01 - 2002-03-07 with estimated minimum and maximum density functions.

From the estimates we may calculate the values at risk in percent as corresponding to a probability, say, $p=0.05$ :

$$
\begin{aligned}
& \mathrm{VaR}^{-}=-2.919-\frac{1.729}{-0.296}\left\{1-[1-21 \cdot \ln (1-0.05)]^{-0.296}\right\}=-1.7825 \\
& \mathrm{VaR}^{+}=3.666+\frac{1.686}{-0.237}\left\{1-[1-21 \cdot \ln (1-0.05)]^{-0.237}\right\}=2.5344 .
\end{aligned}
$$

For a one month horizon we get the $\operatorname{VaR}(21)$ measures as -4.3894 and 5. 2148, respectively. For an investment of $100000 \mathrm{SEK}$, the $\mathrm{VaR}^{-}(21)$ is $100000 \mathrm{SEK} \cdot 0.043984=4398 \mathrm{SEK}$ and $\mathrm{VaR}^{+}(21)=100000$ SEK $\cdot 0.052148=5215$ SEK.

In Figure 3 we exhibit the minimum and maximum returns within months over successive months. It appears that there are larger extreme observations towards the end of the sequence, and that the black-Monday effect for this series is quite small.

Table 2 presents the parameter estimates of the minimum and maximum densities for each of the 40 stock series. Interestingly, we find a common result of $k \leq 0$ in all but 4 of the totally 80 cases. Hence, the Fréchet family receives support. The $k$ estimates are significantly different from zero in close to 50 percent of the cases, and when significant this occurs for both the minimum and maximum densities. In a few instances the estimation algorithm diverged indicating a flat $\log$-likelihood function or that $1+k\left(r_{n i}-\beta\right) / \alpha>0$ is violated for the minimum case. Using instead a leaner Gumbel $(k=0)$ specification gives convergence in these instances as well. 
Table 2: Estimates and standard errors of generalized extreme-value distributions for minima and maxima.

\begin{tabular}{|c|c|c|c|c|c|c|c|c|c|c|c|c|}
\hline \multirow[b]{3}{*}{ Stock series } & \multicolumn{6}{|c|}{ Minimum } & \multicolumn{6}{|c|}{ Maximum } \\
\hline & \multicolumn{2}{|c|}{$k$} & \multicolumn{2}{|c|}{$\beta$} & \multicolumn{2}{|c|}{$\alpha$} & \multicolumn{2}{|c|}{$k$} & \multicolumn{2}{|c|}{$\beta$} & \multicolumn{2}{|c|}{$\alpha$} \\
\hline & Est & $\mathrm{se}$ & Est & $\mathrm{se}$ & Est & $\mathrm{se}$ & Est & $\mathrm{se}$ & Est & $\mathrm{se}$ & Est & $\mathrm{se}$ \\
\hline $\mathrm{ABB}$ & -0.285 & 0.222 & -3.514 & 0.398 & 2.002 & 0.356 & -0.245 & 0.192 & 3.319 & 0.351 & 1.678 & 30.282 \\
\hline Allgon & -0.233 & 0.083 & -4.087 & 0.189 & 2.116 & 0.151 & -0.266 & 0.045 & 5.143 & 0.266 & 2.793 & 0.196 \\
\hline Assa Abloy & -0.006 & 0.083 & -3.622 & 0.150 & 1.555 & 0.137 & -0.151 & 0.133 & 4.554 & 0.216 & 1.790 & 0.191 \\
\hline Astra Zeneca & -0.097 & 0.248 & -2.636 & 0.206 & 1.136 & 0.223 & -0.124 & 0.179 & 2.947 & 0.238 & 1.179 & 0.161 \\
\hline Atlas Copco & -0.083 & 0.050 & -2.705 & 0.103 & 1.236 & 0.077 & -0.201 & 0.066 & 3.135 & 0.117 & 1.380 & 0.091 \\
\hline Autoliv & -0.307 & 0.117 & -2.704 & 0.194 & 1.173 & 0.151 & -0.083 & 0.122 & 3.247 & 0.247 & 1.600 & 0.176 \\
\hline Avesta Polarit & -0.582 & 0.765 & -2.907 & 0.232 & 0.795 & 0.303 & -0.623 & 0.730 & 2.983 & 0.241 & 0.805 & 0.295 \\
\hline Boss Media & -0.288 & 0.176 & -7.289 & 0.486 & 2.442 & 0.451 & 0.119 & 0.218 & 9.684 & 0.726 & 3.758 & 0.592 \\
\hline Electrolux & -0.131 & 0.068 & -2.627 & 0.105 & 1.276 & 0.087 & -0.153 & 0.063 & 2.978 & 0.128 & 1.526 & 0.101 \\
\hline Eniro $^{a}$ & & & & & & & -0.286 & 0.431 & 4.497 & 0.412 & 1.526 & 0.414 \\
\hline Ericsson & -0.296 & 0.090 & -2.919 & 0.139 & 1.729 & 0.134 & -0.237 & 0.085 & 3.666 & 0.138 & 1.686 & 0.125 \\
\hline Europolitan $^{a}$ & -0.090 & 0.125 & -3.789 & 0.189 & 1.719 & 0.183 & & & & & & \\
\hline Föreningssparbanken & -0.033 & 0.137 & -3.065 & 0.158 & 1.195 & 0.114 & 0.056 & 0.093 & 3.621 & 0.176 & 1.481 & 0.165 \\
\hline Gambro & -0.151 & 0.086 & -2.553 & 0.121 & 1.212 & 0.100 & -0.243 & 0.087 & 2.804 & 0.142 & 1.363 & 0.113 \\
\hline $\mathrm{H} \& \mathrm{M}$ & -0.342 & 0.072 & -2.535 & 0.117 & 1.354 & 0.102 & -0.207 & 0.067 & 3.343 & 0.146 & 1.657 & 0.117 \\
\hline Holmen & -0.322 & 0.061 & -3.007 & 0.120 & 1.376 & 0.093 & -0.167 & 0.042 & 3.590 & 0.171 & 1.909 & 0.104 \\
\hline Investor & -0.267 & 0.086 & -2.531 & 0.109 & 1.253 & 0.097 & -0.315 & 0.073 & 2.890 & 0.116 & 1.328 & 30.099 \\
\hline Kinnevik & -0.227 & 0.064 & -3.070 & 0.142 & 1.315 & 0.124 & -0.153 & 0.062 & 3.882 & 0.181 & 1.605 & 0.112 \\
\hline MTG & -0.215 & 0.135 & -4.545 & 0.449 & 2.189 & 0.345 & -0.365 & 0.314 & 5.423 & 0.379 & 2.069 & 0.416 \\
\hline Nokia & -0.320 & 0.084 & -3.893 & 0.155 & 1.906 & 0.156 & -0.103 & 0.055 & 4.991 & 0.246 & 2.681 & 0.148 \\
\hline Nordea $^{a}$ & -0.053 & 0.179 & -3.500 & 0.216 & 1.337 & 0.191 & & & & & & \\
\hline Pharmacia & -0.042 & 0.391 & -3.882 & 0.349 & 1.609 & 0.403 & -0.179 & 0.192 & 3.335 & 0.305 & 1.154 & 0.259 \\
\hline Sandvik & -0.170 & 0.060 & -2.465 & 0.101 & 1.181 & 0.007 & -0.142 & 0.055 & 2.879 & 0.114 & 1.326 & 0.090 \\
\hline SCA & -0.147 & 0.073 & -2.495 & 0.093 & 1.097 & 0.077 & -0.137 & 0.054 & 2.987 & 0.115 & 1.347 & 0.094 \\
\hline Scania & -0.168 & 0.102 & -2.126 & 0.172 & 1.205 & 0.126 & -0.320 & 0.100 & 2.317 & 0.197 & 1.374 & 0.185 \\
\hline SEB & -0.355 & 0.063 & -2.934 & 0.132 & 1.580 & 0.115 & -0.297 & 0.054 & 3.421 & 0.150 & 1.689 & 0.117 \\
\hline Securitas & -0.036 & 0.086 & -3.024 & 0.129 & 1.250 & 0.101 & -0.160 & 0.092 & 3.627 & 0.177 & 1.730 & 0.143 \\
\hline SHB & -0.162 & 0.055 & -2.634 & 0.115 & 1.259 & 0.079 & -0.246 & 0.055 & 3.133 & 0.128 & 1.485 & 0.110 \\
\hline Skandia & -0.125 & 0.080 & -3.198 & 0.138 & 1.635 & 0.110 & -0.249 & 0.075 & 3.623 & 0.156 & 1.843 & 0.139 \\
\hline Skanska & -0.239 & 0.059 & -2.366 & 0.097 & 1.114 & 0.074 & -0.206 & 0.061 & 2.768 & 0.120 & 1.393 & 0.102 \\
\hline SKF & -0.151 & 0.075 & -2.802 & 0.115 & 1.401 & 0.096 & -0.093 & 0.078 & 3.426 & 0.118 & 1.408 & 0.092 \\
\hline Song Networks & -0.243 & 0.313 & -9.992 & 1.291 & 4.688 & 1.158 & -0.174 & 0.366 & 11.13 & 1.560 & 6.771 & 2.743 \\
\hline SSAB & -0.117 & 0.057 & -2.876 & 0.125 & 1.332 & 0.083 & -0.232 & 0.059 & 3.302 & 0.168 & 1.708 & 0.119 \\
\hline Stora Enso & -0.176 & 0.145 & -3.210 & 0.263 & 1.417 & 0.200 & -0.139 & 0.126 & 4.645 & 0.325 & 1.711 & 0.317 \\
\hline Tele2 & -0.124 & 0.138 & -3.649 & 0.217 & 1.638 & 0.188 & -0.129 & 0.077 & 4.281 & 0.277 & 1.923 & 0.211 \\
\hline Telia & -0.218 & 0.387 & -4.341 & 0.536 & 1.601 & 0.303 & -0.201 & 0.487 & 4.559 & 0.480 & 1.992 & 0.475 \\
\hline Tieto Enator & -0.517 & 0.382 & -4.697 & 0.411 & 2.122 & 0.540 & 0.037 & 0.346 & 5.315 & 0.512 & 2.923 & 0.677 \\
\hline Trelleborg & -0.297 & 0.081 & -2.651 & 0.113 & 1.294 & 0.089 & -0.211 & 0.061 & 3.252 & 0.146 & 1.626 & 0.113 \\
\hline Volvo & -0.217 & 0.056 & -2.537 & 0.093 & 1.046 & 0.063 & -0.144 & 0.059 & 2.993 & 0.108 & 1.247 & 0.082 \\
\hline WM-data & -0.118 & 0.041 & -3.524 & 0.152 & 1.731 & 0.113 & 0.039 & 0.053 & 4.198 & 0.210 & 2.542 & 0.153 \\
\hline
\end{tabular}




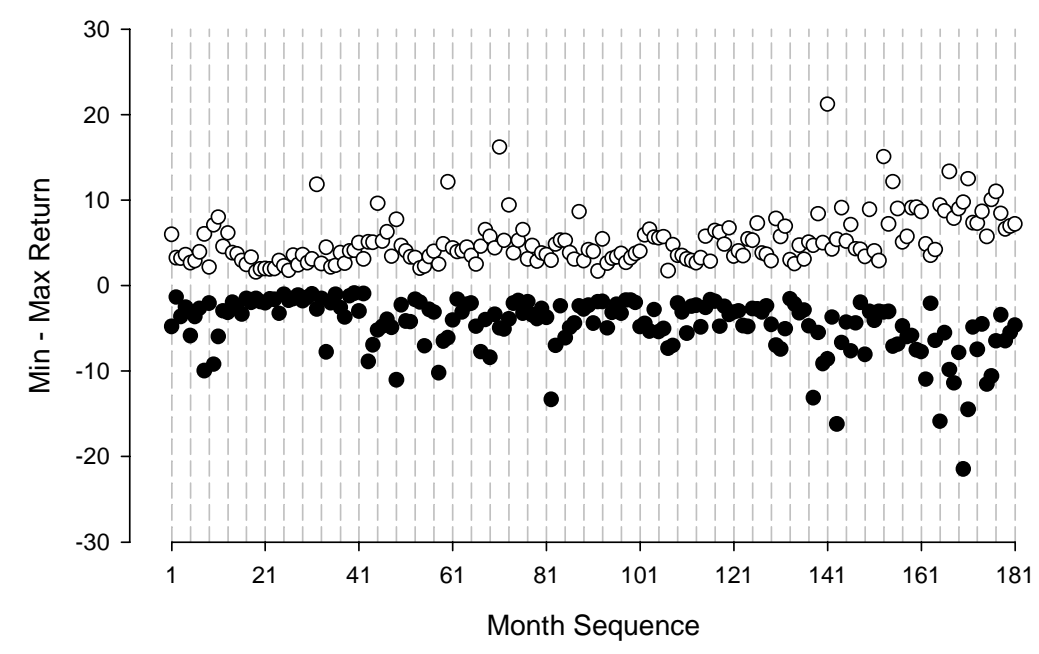

Figure 3: Minimum and maximum returns within months against months for Ericsson B, 1987-01-01 - 2002-03-07.

\subsection{Bivariate Results}

The examination starts with a description of the correlation structure in the 40 stock series. From the correlation structure we obtain the factor structure that may enable us to group, e.g., positively correlated stocks.

The correlations between the returns of the stock series of Table 1 are given in Table 3 . The correlations are in all cases positive and usually well below 0.5. A notable stock with very small correlations with other stocks is SHB. To proceed, we next employ explorative factor analysis with Varimax rotation. By this we hope to see whether there is an underlying factor structure and a pattern in the factor loadings that may ease the interpretation of co-dependencies between return series. The use of factor analysis in financial settings is discussed in, e.g., Campbell, Lo and MacKinley (1997) and Press (1982).

For this purpose we leave out stock series shorter than 1000 observations, i.e. those with less than about four years of observations. To select the number of factors we employ Kaiser's rule. By this criterion we find six factors that explain 49.8 percent of the total variation in the resulting 30 stock return series. The first factor explains 27.8 percent of the variation in the series, while the other five factors add $3.5-6.5$ percent each. The estimated factor loadings are given in Table 4, while Figure 4 presents the factor structure in a graphical form. For the figure we only depict factor loadings exceeding 0.5 in absolute value.

The first factor is made up of stocks for manufacturing companies. The second factor consists of telecom companies. The third appears difficult to cathegorize, though it contains three Wallenberg-sphere companies. Factor four is comprised of three banks and the sixth factor is made up solely by the remaining bank, SHB. The fifth factor is made up of two security 
Table 3: Correlations between return series. Pairwise missing observations are excluded. (The orders vertically and horizontally are the same.)

\begin{tabular}{|c|c|}
\hline tock & \\
\hline ABB Ltd & 1.0 \\
\hline Allgon & .191 .0 \\
\hline Assa Abloy & .21 .181 .0 \\
\hline Astra Zeneca & .13.01. 10 1.0 \\
\hline Atlas Copco A & .36 .17 .14 .051 .0 \\
\hline Autoliv SDB & 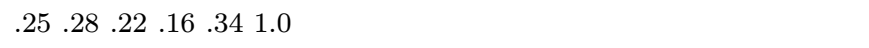 \\
\hline Avesta Polarit & .16.19. 29. 21. 28 1.0 \\
\hline Boss Media & .25.25. 22. 25. 26. 20 1.0 \\
\hline Electrolux B & 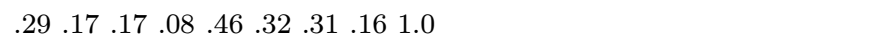 \\
\hline Eniro & .25. 18. 31. 09. 25. 25. 25 19.0 \\
\hline Europolitan B & 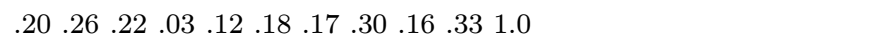 \\
\hline Föreningssparbanken & 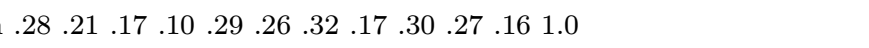 \\
\hline Gambro B & .15.14. 14. 14. 14. 14. 25. 25. 18. 18. 25. \\
\hline $\mathrm{H} \& \mathrm{M} B$ & 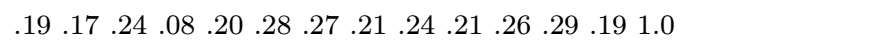 \\
\hline Holmen B & .21. 1.0 \\
\hline Investor B & \\
\hline Kinnevik B & 31.0 \\
\hline MTG B & \\
\hline Nokia & 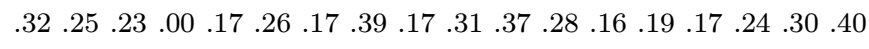 \\
\hline Nordea & 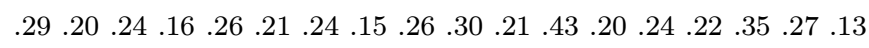 \\
\hline Pharmacia C & 08. 01. 10. 12. 06. 13. 07. 02. 06. 09. 05. 11. 03. 05. 41. 06. 05. 13. \\
\hline Sandvik AB & 17. 26. 29. 26. 18. 28. 35. 16. 28. 30. 20. 35. 35. 35.38 .13 .18 .07$. \\
\hline SCA B & 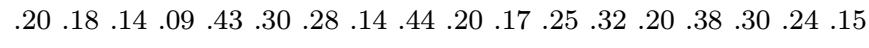 \\
\hline Scania B & 15. 24. 43. 30. 21. 11. 20. 15. 24. 25. 16. 16. 24. 28. 16.22 .16$. \\
\hline SEB A & 26. 19. 20. 17. 19. 17. 49. 19. 27. 24. 23. 34. 29. 23. 34.14 .20$. \\
\hline Securitas & 17. 19. 20. 08. 19. 12. 15. 17. 21. 18. 15. 19. 20. 15. 15. 28. 13. 12. \\
\hline SHB A & 08. 01. 01. 03. 06. 02. 03. 02. 09. 04. 05. 14. 03. 01. 01. 00. 04. \\
\hline SKF B & 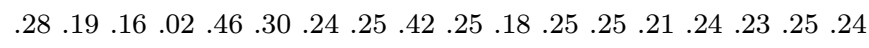 \\
\hline Skandia & 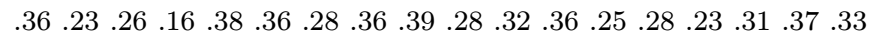 \\
\hline Skanska & 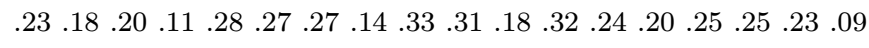 \\
\hline Song Networks & 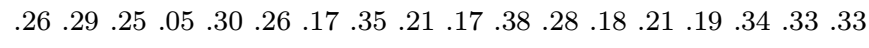 \\
\hline SSAB A & 15. 24. 28. 30. 19. 29. 22. 15. 29. 34. 29. \\
\hline Stora Enso Ser R & 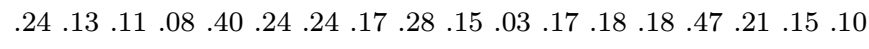 \\
\hline Tele $2 \mathrm{~B}$ & 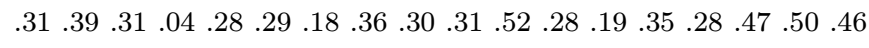 \\
\hline Telia & 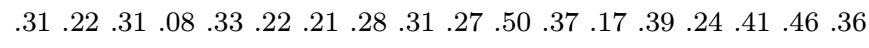 \\
\hline Tieto Enator & 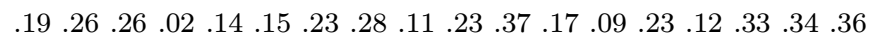 \\
\hline Trelleborg B & 19. 25. 28. 26. 21. 32. 28. 16. 21. 35. 20. 30. 27. 29. 14. 18. 19.20. \\
\hline WM-data & 34. 26. 17. 08. 17. 12. 23. 31. 28. 16. 23. 23. 26. 26. 23. 26.17. \\
\hline Volvo B & 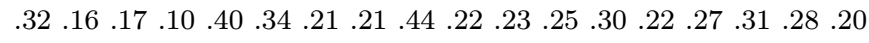 \\
\hline Ericsson B & 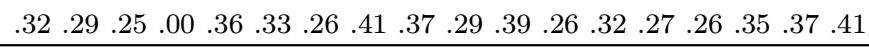 \\
\hline
\end{tabular}


Table 3: Continued.

\begin{tabular}{|c|c|}
\hline Stock & \\
\hline $\begin{array}{l}\text { Nokia } \\
\end{array}$ & 1.0 \\
\hline Nordea & .261 .0 \\
\hline Pharmacia & .01 .141 .0 \\
\hline Sandvik & .13.09 1.0 \\
\hline SCA & .17. 23.09. 27 1.0 \\
\hline Scania & .25. 20. 20. 26 1.0 \\
\hline SEB & .12. 47. 05. 25. 24 1.0 \\
\hline Securitas & . 22. 18. 10. 16. 16. 16. 16.0 \\
\hline SHB & 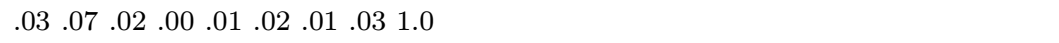 \\
\hline SKF B & . 19.04 . 25 1.0 \\
\hline Skandia & 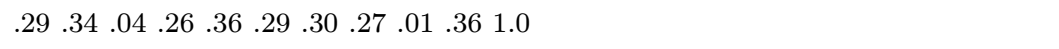 \\
\hline Skanska & 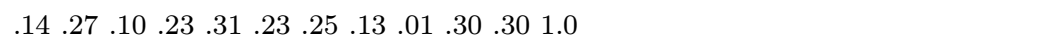 \\
\hline Song Netw & 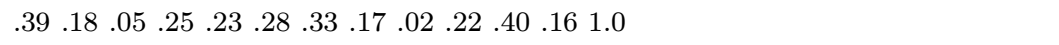 \\
\hline SSAB & \\
\hline Stora Enso & 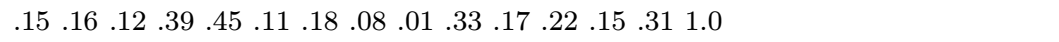 \\
\hline Tele 2 & \\
\hline Telia & .45.39. 08.33. 29. 23. 1.0 \\
\hline Tieto Enat & 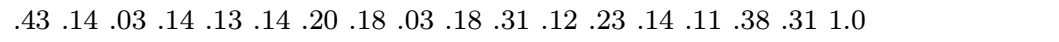 \\
\hline Trelleborg & \\
\hline WM-data & 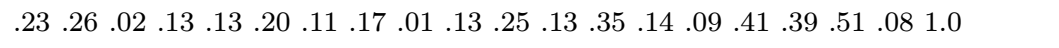 \\
\hline Volvo & 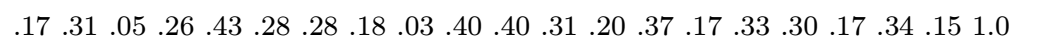 \\
\hline Ericsson & 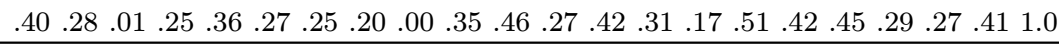 \\
\hline
\end{tabular}

oriented companies.

The given correlations are based on the two basic assumptions that (i) they are constant over time, and (ii) they are constant across the ranges of the returns. Both assumptions have been criticized in the literature. For example, Tsay (2000, ch. 9) discusses time-varying correlation models. The correlations between minima, between maxima and between minima and maxima in return series are illustrated in Longin (2000). As we abstain from employing more tightly model-based approaches as, e.g., GARCH models for volatility, we also abstain from using time-varying correlation models here. In a practical sense employing GARCH and variable correlation models is, however, perfectly feasible.

Results for bivariate associations between extremum values are given for the pairs of return series that are included in Figure 4 and also in the category Most traded on the A-list of Stockholmsbörsen. Europolitan, Kinnevik and Tele 2 are therefore not retained. Figure 5 illustrates the type of outcome such an exercise may produce by the pair Ericsson B and SEB A. The $\rho$ estimate (cf. Tiago de Oliviera, 1973) between maxima of Ericsson B and SEB $\mathrm{B}$ is 0.499 , while the Pearson correlation is 0.32 , etc. The correlation between all returns is 0.25 . We find indications for a variable correlation across the range of returns.

Figure 6 gives the corresponding test statistics $\bar{\chi}$, which is closely related to correlations, for varying cut-offs in maximum as well as minimum directions. In no case is there a significant test result, and we conclude that the series are asymptotically independent. Note that the figure is produced under no corrections for conditional heteroskedasticity. For the combination Ericsson down and SEB up the test outcome is 0.238 with an upper limit 0.977 of its confidence interval. This is relative close to one, which would have indicated 
Table 4: Varimax rotated loadings in factor analysis. Series shorter than 1000 return observations are excluded. Loadings smaller than 0.2 in absolute value are excluded.

\begin{tabular}{|c|c|c|c|c|c|c|}
\hline & \multicolumn{6}{|c|}{ Component } \\
\hline & 1 & 2 & 3 & 4 & 5 & 6 \\
\hline Allgon & & 0.48 & & & & \\
\hline Assa Abloy & & 0.22 & & & 0.65 & \\
\hline Atlas Copco A & 0.69 & & & & & \\
\hline Autoliv SDB & 0.39 & 0.22 & & & 0.31 & \\
\hline Electrolux B & 0.68 & & & & & \\
\hline Ericsson B & 0.43 & 0.59 & & & & \\
\hline Europolitan B & & 0.73 & & & & \\
\hline Föreningssparbanken & & & 0.24 & 0.74 & & \\
\hline Gambro B & 0.26 & & 0.58 & & & \\
\hline H \& M B & & 0.28 & & 0.20 & 0.30 & -0.22 \\
\hline Holmen B & 0.27 & & 0.57 & & & \\
\hline Investor B & & 0.29 & 0.68 & & & \\
\hline Kinnevik B & & 0.52 & 0.27 & & & \\
\hline Nokia & & 0.66 & & & & \\
\hline Nordea & & & & 0.67 & & \\
\hline Sandvik AB & 0.30 & & 0.42 & 0.23 & 0.24 & \\
\hline SCA B & 0.65 & & 0.27 & & & \\
\hline Scania B & & & 0.51 & & 0.20 & \\
\hline SEB A & 0.21 & & & 0.79 & & \\
\hline Securitas & & & & & 0.75 & \\
\hline SHB A & & & & & & 0.89 \\
\hline SKF & 0.69 & & & & & \\
\hline Skandia & 0.47 & 0.42 & & 0.24 & 0.22 & \\
\hline Skanska & 0.39 & & 0.26 & 0.29 & & \\
\hline SSAB A & 0.54 & & 0.34 & & & \\
\hline Tele2 B & & 0.75 & 0.20 & & & \\
\hline Trelleborg B & 0.41 & & 0.43 & & & \\
\hline WM-data & & 0.48 & & & 0.31 & \\
\hline Volvo B & 0.62 & & & & & \\
\hline
\end{tabular}



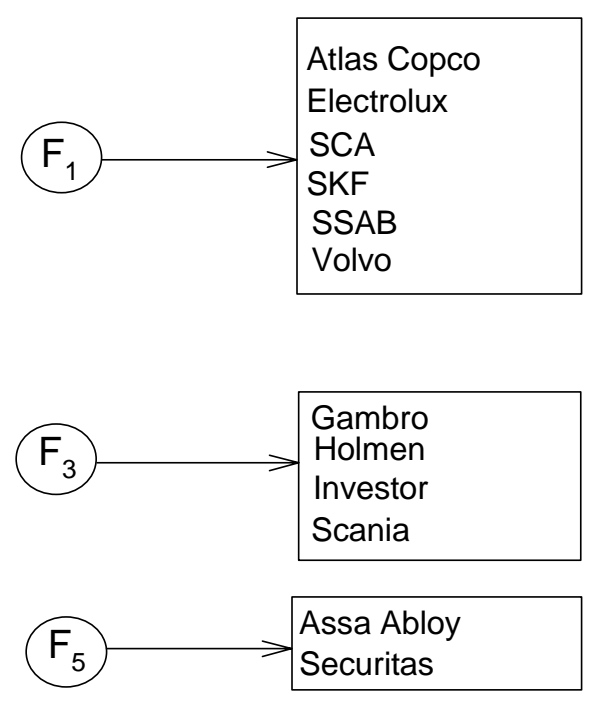
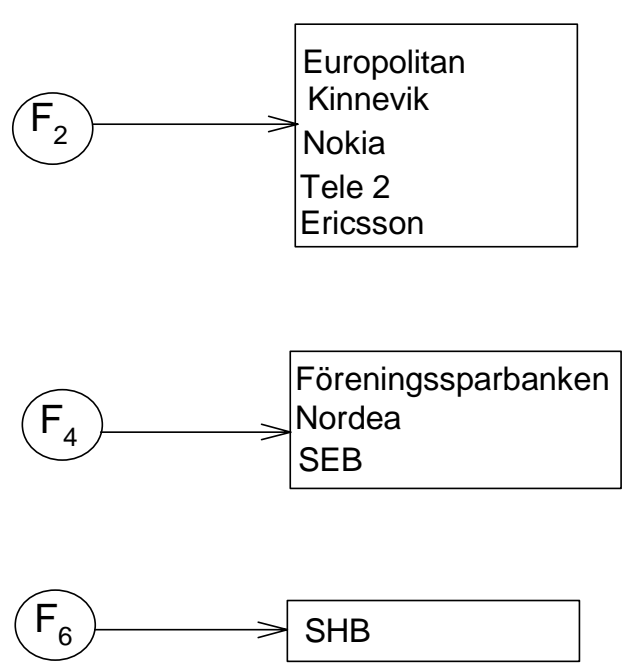

Figure 4: Factor loading structure (loadings exceeding 0.5 in absolute value).

asymptotic dependence.

Table 5 gives the estimates of $\bar{\chi}$ for the four quadrants indicated in Figure 6 for all series. In all cases $\bar{\chi}^{*}$ is significantly smaller than one, and hence the variables are taken to be asymptotically independent. We may then also take $\chi=0$. The results of Poon et al. (2002) indicate that heteroskedasticity filtered $\bar{\chi}^{*}$ estimates are smaller than the reported unfiltered ones. This indicates that the reported $\bar{\chi}^{*}$ are rather overestimates than underestimates and therefore gives added supported for the asymptotic independence finding.

The table indicates by an asterix when $\bar{\chi}^{*}$ is significantly different from zero. The result of more likely crashes than upswings as indicated by Longin and Solnik (2001) and others from a smaller measure in the Max/Max quadrant than in the Min/Min does not receive a coherent support. The overall ratio between the $\bar{\chi}^{*}$ s for upswings and crashes is not significantly different from one. Obviously, there are some differences between individual stocks. Size ranking $\bar{\chi}^{*}$ over the four quadrants and then studying the distribution across stocks reveals almost uniform distributions with roughly 0.25 proportions for ranking within quadrants as well as between quadrants. In addition, the signs of $\bar{\chi}^{*}$ are in most cases positive though of rather small size.

\section{Conclusions}

We find strong support for the Fréchet family for the minima and maxima of the univariate stock return series. Based on this distribution value-at-risk and related measures can be obtained without specifying a model directly for the return series. 


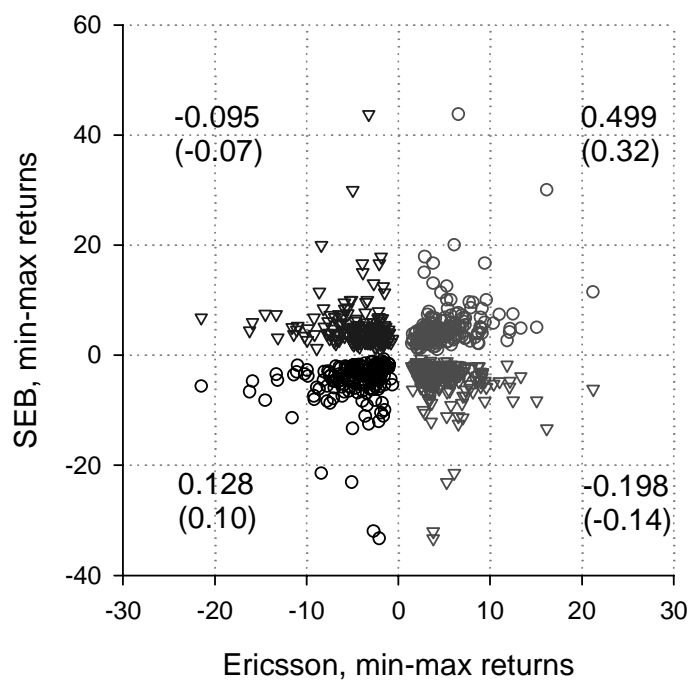

Figure 5: Relationships between extremes of Ericsson B and SEB A using monthly minima and maxima. The first number of each quadrant is the $\rho$ ad hoc estimate of Longin and Tiago de Oliviera and the one in parenthesis is the conventional correlation coefficient.

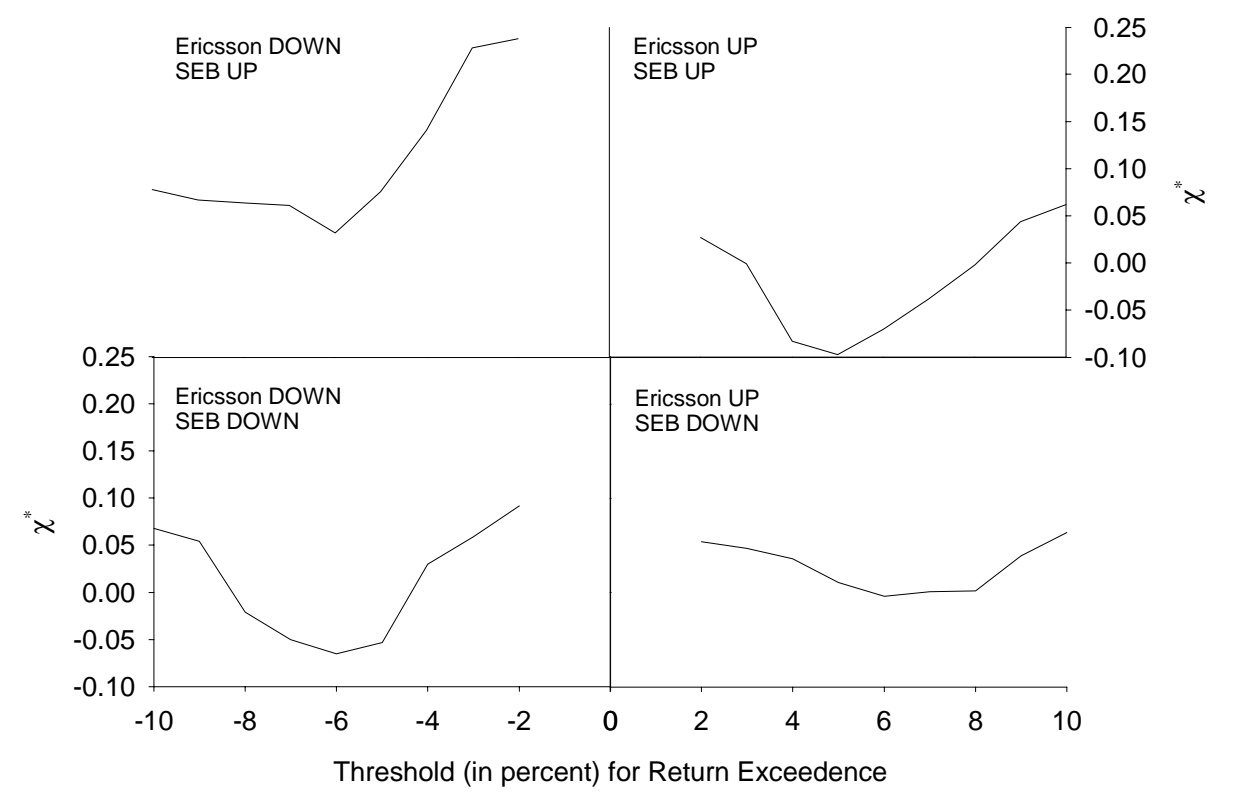

Figure 6: Test statistic $\bar{\chi}^{*}$ between extreme returns in Ericsson B and SEB A against threshold in percent. First quadrant corresponds to up-crossings in both series, the third to down-crossings in both, etc. 
Table 5: Estimates $\bar{\chi}^{*}$ for pairs of series. Asterix indicates significant difference from zero at the 0.05 level.

\begin{tabular}{|c|c|c|c|c|c|}
\hline & $\operatorname{Max} / \operatorname{Max}$ & Max/Min & Min/Max & Min/Min & $n$ \\
\hline \multicolumn{6}{|l|}{ Ericsson vs } \\
\hline SEB & -0.097 & 0.011 & 0.076 & -0.053 & 3810 \\
\hline Atlas Copco & $0.270 *$ & $0.349 *$ & $0.192 *$ & $0.298 *$ & 3810 \\
\hline Electorlux & $0.176 *$ & $0.258 *$ & $0.223 *$ & 0.104 & 3810 \\
\hline SCA & -0.007 & 0.042 & 0.068 & -0.099 & 3809 \\
\hline SKF & 0.036 & 0.038 & 0.149 & 0.094 & 3810 \\
\hline SSAB & 0.121 & 0.127 & 0.119 & 0.150 & 3184 \\
\hline Volvo & $0.194 *$ & 0.025 & -0.045 & $0.243 *$ & 3810 \\
\hline Nokia & $0.264 *$ & $0.187 *$ & $0.182 *$ & $0.211 *$ & 3754 \\
\hline Gambro & $0.245 *$ & -0.013 & -0.071 & 0.079 & 2671 \\
\hline Holmen & 0.052 & -0.011 & -0.136 & 0.076 & 3751 \\
\hline Investor & 0.121 & 0.108 & 0.096 & 0.128 & 3488 \\
\hline Scania & 0.049 & 0.034 & 0.041 & -0.053 & 1485 \\
\hline Föreningssparbanken & 0.078 & 0.058 & -0.042 & 0.045 & 1692 \\
\hline Nordea & 0.031 & -0.027 & 0.321 & 0.112 & 1063 \\
\hline Assa Abloy & 0.168 & 0.100 & 0.213 & 0.091 & 1838 \\
\hline Securitas & -0.050 & -0.092 & -0.088 & -0.060 & 2527 \\
\hline SHB & 0.156 & 0.081 & 0.162 & 0.152 & 3755 \\
\hline \multicolumn{6}{|l|}{ SEB vs } \\
\hline Atlas Copco & 0.029 & 0.029 & 0.030 & $0.184 *$ & 3810 \\
\hline Electrolux & 0.059 & -0.002 & 0.042 & -0.025 & 3810 \\
\hline SCA & 0.025 & $0.280 *$ & $0.214 *$ & 0.159 & 3809 \\
\hline SKF & -0.030 & -0.022 & -0.116 & -0.065 & 3810 \\
\hline SSAB & 0.059 & -0.055 & -0.066 & -0.041 & 3184 \\
\hline Volvo & 0.014 & -0.123 & -0.084 & 0.017 & 3810 \\
\hline Nokia & 0.078 & 0.092 & $0.168 *$ & 0.004 & 3754 \\
\hline Gambro & $0.382 *$ & $0.270 *$ & 0.126 & $0.324 *$ & 2671 \\
\hline Holmen & -0.089 & -0.021 & 0.043 & 0.099 & 3751 \\
\hline Investor & 0.042 & 0.051 & 0.149 & -0.004 & 3488 \\
\hline Scania & 0.051 & 0.008 & -0.062 & 0.100 & 1485 \\
\hline Föreningssparbanken & -0.105 & 0.150 & 0.146 & 0.036 & 1692 \\
\hline Nordea & -0.046 & -0.047 & -0.135 & -0.125 & 1063 \\
\hline Assa Abloy & 0.086 & 0.088 & 0.233 & 0.012 & 1838 \\
\hline Securitas & -0.092 & $0.241 *$ & 0.148 & -0.024 & 2527 \\
\hline SHB & -0.099 & 0.049 & 0.155 & -0.131 & 3755 \\
\hline
\end{tabular}


Table 5: Continued.

\begin{tabular}{|c|c|c|c|c|c|}
\hline & "Max/Max & "Max/Min & "Min/Max & Min/Min & $\overline{l n}$ \\
\hline \multicolumn{6}{|l|}{ Atlas Copco vs } \\
\hline Electrolux & 0.071 & -0.027 & $0.173^{*}$ & 0.091 & 3810 \\
\hline SCA & 0.129 & -0.083 & -0.006 & 0.038 & 3809 \\
\hline SKF & 0.145 & $0.178 *$ & 0.077 & -0.017 & 3810 \\
\hline SSAB & 0.140 & 0.003 & -0.018 & 0.080 & 3184 \\
\hline Volvo & 0.063 & -0.027 & -0.026 & 0.035 & 3810 \\
\hline Nokia & -0.064 & $0.253 *$ & 0.160 & -0.049 & 3754 \\
\hline Gambro & -0.038 & -0.058 & -0.099 & -0.053 & 2671 \\
\hline Holmen & 0.109 & 0.090 & 0.125 & 0.025 & 3751 \\
\hline Investor & -0.005 & 0.172 & 0.132 & 0.004 & 3488 \\
\hline Scania & 0.258 & -0.097 & 0.028 & 0.052 & 1485 \\
\hline Föreningssparbanken & 0.160 & 0.000 & 0.032 & -0.028 & 1692 \\
\hline Nordea & -0.101 & -0.057 & 0.062 & 0.027 & 1063 \\
\hline Assa Abloy & 0.016 & 0.257 & 0.039 & -0.063 & 1838 \\
\hline Securitas & -0.013 & 0.038 & 0.006 & 0.014 & 2527 \\
\hline SHB & -0.110 & 0.031 & 0.059 & 0.002 & 3755 \\
\hline \multicolumn{6}{|l|}{ Electrolux vs } \\
\hline SCA & -0.069 & -0.008 & 0.101 & 0.062 & 3809 \\
\hline SKF & 0.058 & 0.039 & 0.017 & -0.021 & 3810 \\
\hline SSAB & -0.016 & 0.023 & 0.052 & -0.001 & 3184 \\
\hline Volvo & $0.221 *$ & 0.156 & 0.101 & $0.256 *$ & 3810 \\
\hline Nokia & 0.081 & 0.118 & 0.119 & 0.106 & 3754 \\
\hline Gambro & -0.003 & 0.102 & 0.189 & 0.057 & 2671 \\
\hline Holmen & 0.155 & 0.007 & 0.025 & 0.095 & 3751 \\
\hline Investor & -0.024 & 0.122 & 0.042 & 0.008 & 3488 \\
\hline Scania & 0.174 & 0.051 & -0.048 & -0.095 & 1485 \\
\hline Föreningssparbanken & -0.075 & -0.059 & 0.078 & 0.035 & 1692 \\
\hline Nordea & -0.016 & -0.018 & -0.036 & 0.011 & 1063 \\
\hline Assa Abloy & 0.215 & $0.264 *$ & 0.063 & $0.437 *$ & 1838 \\
\hline Securitas & 0.043 & 0.161 & 0.117 & 0.206 & 2527 \\
\hline SHB & 0.166 & 0.167 & $0.258 *$ & 0.068 & 3755 \\
\hline \multicolumn{6}{|l|}{ SCA vs } \\
\hline SKF & 0.069 & $0.193 *$ & 0.164 & 0.070 & 3810 \\
\hline SSAB & -0.126 & $0.278 *$ & 0.177 & -0.068 & 3184 \\
\hline Volvo & -0.078 & 0.048 & -0.068 & -0.006 & 3810 \\
\hline Nokia & 0.091 & -0.004 & 0.057 & 0.144 & 3754 \\
\hline Gambro & 0.179 & $0.302 *$ & 0.007 & 0.043 & 2671 \\
\hline Holmen & $0.178 *$ & 0.048 & 0.092 & 0.027 & 3751 \\
\hline Investor & 0.118 & 0.134 & 0.093 & $0.179 *$ & 3488 \\
\hline Scania & $0.337 *$ & 0.045 & 0.168 & 0.192 & 1485 \\
\hline Föreningssparbanken & $0.341 *$ & $0.278 *$ & $0.344 *$ & 0.267 & 1692 \\
\hline Nordea & 0.005 & -0.096 & -0.100 & 0.107 & 1063 \\
\hline Assa Abloy & -0.038 & -0.033 & 0.029 & -0.061 & 1838 \\
\hline Securitas & 0.132 & -0.010 & 0.091 & 0.109 & 2527 \\
\hline SHB & 0.094 & -0.101 & -0.012 & -0.034 & 3755 \\
\hline
\end{tabular}


Table 5: Continued.

\begin{tabular}{|c|c|c|c|c|c|}
\hline & Max/Max & Max/Min & Min/Max & Min/Min & $n$ \\
\hline \multicolumn{6}{|l|}{ SKF vs } \\
\hline SSAB & 0.096 & 0.111 & 0.169 & 0.119 & 3184 \\
\hline Volvo & 0.054 & 0.102 & -0.011 & -0.108 & 3810 \\
\hline Nokia & 0.070 & -0.009 & 0.142 & 0.059 & 3754 \\
\hline Gambro & -0.038 & 0.063 & -0.089 & 0.148 & 2671 \\
\hline Holmen & 0.065 & 0.056 & 0.046 & 0.091 & 3751 \\
\hline Investor & 0.126 & 0.040 & 0.095 & 0.085 & 3488 \\
\hline Scania & 0.062 & 0.173 & 0.077 & -0.026 & 1485 \\
\hline Föreningssparbanken & 0.087 & 0.052 & $0.276 *$ & 0.251 & 1692 \\
\hline Nordea & 0.031 & -0.033 & 0.092 & -0.130 & 1063 \\
\hline Assa Abloy & 0.031 & 0.003 & -0.047 & 0.130 & 1838 \\
\hline Securitas & 0.034 & 0.108 & 0.052 & 0.054 & 2527 \\
\hline SHB & 0.079 & 0.016 & 0.025 & 0.118 & 3755 \\
\hline \multicolumn{6}{|l|}{ SSAB vs } \\
\hline Volvo & $0.241 *$ & 0.126 & 0.127 & -0.124 & 3810 \\
\hline Nokia & $-0.203 *$ & $-0.225 *$ & $-0.154 *$ & -0.073 & 3754 \\
\hline Gambro & 0.156 & 0.142 & 0.096 & 0.067 & 2671 \\
\hline Holmen & $0.357 *$ & -0.046 & 0.167 & 0.073 & 3751 \\
\hline Investor & 0.067 & 0.064 & 0.074 & 0.037 & 3488 \\
\hline Scania & 0.217 & 0.050 & 0.106 & 0.051 & 1485 \\
\hline Föreningssparbanken & 0.252 & 0.172 & -0.023 & -0.097 & 1692 \\
\hline Nordea & -0.060 & -0.098 & $0.418 *$ & 0.234 & 1063 \\
\hline Assa Abloy & 0.252 & 0.163 & 0.029 & 0.095 & 1838 \\
\hline Securitas & -0.018 & 0.134 & 0.166 & 0.130 & 2527 \\
\hline SHB & -0.086 & -0.034 & -0.048 & 0.088 & 3755 \\
\hline \multicolumn{6}{|l|}{ Volvo vs } \\
\hline Nokia & 0.083 & 0.119 & 0.093 & $0.189 *$ & 3754 \\
\hline Gambro & -0.078 & 0.099 & 0.067 & -0.100 & 2671 \\
\hline Holmen & 0.123 & -0.023 & 0.058 & 0.141 & 3751 \\
\hline Investor & 0.155 & -0.024 & -0.002 & $0.236 *$ & 3488 \\
\hline Scania & 0.043 & 0.007 & 0.052 & 0.004 & 1485 \\
\hline Föreningssparbanken & 0.024 & $-0.273 *$ & $-0.199 *$ & 0.008 & 1692 \\
\hline Nordea & 0.020 & 0.078 & -0.011 & 0.113 & 1063 \\
\hline Assa Abloy & $0.342 *$ & -0.045 & 0.080 & $0.294 *$ & 1838 \\
\hline Securitas & 0.061 & 0.168 & $0.307 *$ & 0.030 & 2527 \\
\hline SHB & 0.092 & 0.101 & 0.063 & 0.068 & 3755 \\
\hline \multicolumn{6}{|l|}{ Nokia vs } \\
\hline Gambro & 0.119 & 0.048 & -0.067 & 0.099 & 2671 \\
\hline Holmen & -0.051 & -0.058 & -0.052 & -0.037 & 3751 \\
\hline Investor & 0.080 & 0.078 & 0.022 & 0.057 & 3488 \\
\hline Scania & 0.208 & $0.414 *$ & $0.477 *$ & 0.044 & 1485 \\
\hline Föreningssparbanken & -0.034 & 0.262 & 0.181 & 0.231 & 1692 \\
\hline Nordea & -0.124 & 0.263 & 0.165 & 0.164 & 1063 \\
\hline Assa Abloy & $0.324 *$ & 0.224 & 0.169 & 0.225 & 1838 \\
\hline Securitas & 0.202 & 0.148 & 0.104 & 0.136 & 2527 \\
\hline SHB & 0.002 & 0.039 & 0.103 & 0.011 & 3755 \\
\hline
\end{tabular}


Table 5: Continued.

\begin{tabular}{|c|c|c|c|c|c|}
\hline & $\operatorname{Max} / \operatorname{Max}$ & Max/Min & Min/Max & Min/Min & $n$ \\
\hline \multicolumn{6}{|l|}{ Gambro vs } \\
\hline Holmen & $0.308 *$ & $0.214 *$ & $0.440 *$ & $0.321 *$ & 3751 \\
\hline Investor & 0.109 & 0.091 & $0.374 *$ & $0.341 *$ & 3488 \\
\hline Scania & -0.182 & 0.057 & 0.042 & -0.052 & 1485 \\
\hline Föreningssparbanken & 0.011 & 0.132 & 0.208 & 0.236 & 1692 \\
\hline Nordea & 0.257 & 0.125 & 0.033 & 0.049 & 1063 \\
\hline Assa Abloy & 0.103 & -0.006 & 0.152 & -0.016 & 1838 \\
\hline Securitas & 0.053 & 0.137 & -0.017 & 0.167 & 2527 \\
\hline SHB & 0.157 & 0.120 & $0.195 *$ & -0.048 & 3755 \\
\hline \multicolumn{6}{|l|}{ Holmen vs } \\
\hline Investor & $0.199 *$ & 0.053 & -0.013 & $0.252 *$ & 3488 \\
\hline Scania & -0.059 & -0.082 & 0.029 & 0.078 & 1485 \\
\hline Föreningssparbanken & 0.148 & 0.173 & 0.073 & 0.113 & 1692 \\
\hline Nordea & 0.216 & -0.092 & -0.095 & 0.141 & 1063 \\
\hline Assa Abloy & $0.283 *$ & 0.088 & 0.146 & $0.343 *$ & 1838 \\
\hline Securitas & -0.016 & 0.094 & 0.014 & -0.003 & 2527 \\
\hline SHB & 0.112 & $0.309 *$ & $0.307 *$ & 0.129 & 3755 \\
\hline \multicolumn{6}{|l|}{ Investor vs } \\
\hline Scania & 0.020 & 0.051 & 0.185 & 0.269 & 1485 \\
\hline Föreningssparbanken & -0.140 & 0.059 & 0.015 & -0.021 & 1692 \\
\hline Nordea & -0.075 & -0.096 & 0.124 & 0.033 & 1063 \\
\hline Assa Abloy & 0.220 & 0.028 & -0.018 & $0.363 *$ & 1838 \\
\hline Securitas & $0.243 *$ & 0.038 & 0.104 & 0.199 & 2527 \\
\hline SHB & 0.086 & 0.050 & 0.114 & $0.231 *$ & 3755 \\
\hline \multicolumn{6}{|l|}{ Scania vs } \\
\hline Föreningssparbanken & -0.118 & -0.048 & -0.115 & 0.063 & 1692 \\
\hline Nordea & 0.113 & 0.028 & 0.134 & 0.261 & 1063 \\
\hline Assa Abloy & -0.063 & -0.108 & 0.133 & 0.016 & 1838 \\
\hline Securitas & 0.103 & -0.060 & 0.016 & $0.252 *$ & 2527 \\
\hline SHB & 0.093 & 0.048 & 0.135 & 0.043 & 3755 \\
\hline \multicolumn{6}{|c|}{ Föreningssparbanken vs } \\
\hline Nordea & 0.174 & $0.390 *$ & $0.394 *$ & 0.204 & 1063 \\
\hline Assa Abloy & -0.124 & -0.052 & -0.163 & -0.052 & 1838 \\
\hline Securitas & 0.140 & 0.063 & 0.099 & 0.147 & 2527 \\
\hline SHB & 0.129 & 0.010 & 0.058 & 0.013 & 3755 \\
\hline \multicolumn{6}{|l|}{ Nordea vs } \\
\hline Assa Abloy & 0.087 & 0.001 & 0.088 & 0.010 & 1838 \\
\hline Securitas & 0.208 & $0.226 *$ & $0.221 *$ & 0.198 & 2527 \\
\hline $\mathrm{SHB}$ & 0.111 & $0.284 *$ & 0.100 & $0.266 *$ & 3755 \\
\hline \multicolumn{6}{|l|}{ Assa Abloy vs } \\
\hline Securitas & $0.238 *$ & $0.278 *$ & $0.446 *$ & 0.053 & 2527 \\
\hline SHB & 0.088 & 0.010 & -0.008 & 0.056 & 3755 \\
\hline \multicolumn{6}{|l|}{ Securitas vs } \\
\hline SHB & 0.047 & 0.103 & 0.129 & 0.111 & 3755 \\
\hline
\end{tabular}


There are significant (Pearson) correlations between a number of the pairs of return series. The results from the testing against asymptotic independence indicate that the correlations vanish for large returns. The latter is based on truncated distributions while the former is not. Longin and Solnik (2001) discuss the case of a correlated bivariate normal variable and give some reasons for this type of disparity in results. The finding that series are frequently asymptotically independent has an interesting financial implication. If series are asymptotically independent portfolio risk may be overestimated.

\section{REFERENCES}

Byström, H.N.E. (2001). Managing Extreme Risks in Tranquil and Volatile Markets Using Conditional Extreme Value Theory. Working Paper. Department of Economics, Lund University.

Campbell, J.Y., Lo, A.W. and MacKinley, A.C. (1997). The Econometrics of Financial Markets. Princeton University Press, Princeton.

Coles, S., Heffernan, J. and Tawn, J. (1999). Dependence Measures for Extreme Value Analyses. Extremes 2, 339-365.

Gourieroux, C. and Jasiak, J. (2002). Financial Econometrics. Princeton University Press, Princeton.

Longin, F.M. (2000). From Value at Risk to Stress Testing: The Extreme Value Approach. Journal of Banking \& Finance 24, 1097-1130.

Longin, F. and Solnik, B. (2001). Extreme Correlation of International Equity Markets. Journal of Finance LVI, 649-676.

Poon, S-H, Rockinger, M. and Tawn, J. (2002). Modelling Extreme-Value Dependence in International Stock Markets. Working Paper. Department of Accounting and Finance, University of Strathclyde.

Press, S.J. (1982). Applied Multivariate Analysis: Using Bayesian and Frequentist Methods of Inference. Krieger, Malabar, Fl.

Tsay, R. (2002). Analysis of Financial Time Series. Wiley, New York. 